\title{
MODEL COOPERATIVE LEARNING PADA PEMBELAJARAN ANALISIS BUSANA UNTUK MENINGKATKAN MOTIVASI DAN HASIL BELAJAR MAHASISWA
}

\begin{abstract}
As-as Setiawati ${ }^{1}$
Abstrak : Penelitian Model Cooperative Learning Pada Pembelajaran Analisis Busana Untuk Meningkatkan Motivasi dan Hasil Belajar Mahasiswa, dilakukan dengan menggunakan pendekatan Classroom Action Research (CAR), melalui empat siklus dalam rangka memecahkan masalah sampai masalah dapat terpecahkan. Subjek penelitian dipilih dosen (team teaching) dan mahasiswa. Inti dari cooperative learning adalah belajar berkolaborasi dalam kelompok kooperatif. Pada saat mahasiswa belajar dalam kelompok akan berkembang suasana belajar yang terbuka dalam dimensi kesejawatan, karena pada saat itu akan terjadi proses belajar kolaboratif dalam hubungan pribadi yang saling membutuhkan. Pada saat itu juga mahasiswa yang belajar dalam kelompok kecil akan tumbuh dan berkembang pola belajar tutor sebaya (peer group) dan belajar secara bekerjasama (cooperative). Merasakan duka dan suka bersama, gagal dan berhasil dirasakan bersama. Memiliki tanggung jawab terhadap tiap mahasiswa lain dalam kelompoknya, disamping tanggung jawab terhadap diri sendiri, dalam mempelajari materi yang dihadapi. Keadaan inilah yang meningkatkan motivasi belajar mahasiswa dalam belajar Analisis Model Busana khususnya pecah pola busana.

Abstract: Cooperative Learning Model in Fashion Analysis Study and it's Role in Increasing Student's Motivation and Study Result, was conducted using the Classroom Action Research (CAR) approach, going through four cycle in order to solve problem and until the problem is solved. The key in cooperative learning is learning to collaborate in a cooperative group. When students study in group, an open study atmosphere will be created in terms of partnership, because at that very exact moment a collaborative learning process will be born in a symbiotic personal relationship. And at that moment also, peer group and cooperative learning pattern will be developed. To experience happiness and sadness, failure and success together. Having responsible for everyone else in the group, besides the responsibility for themselves, in learning faced material. This situation will increase student's motivation in Fashion Model Analysis, particularly fashion pattern scattering.
\end{abstract}

Kata kunci : Model Cooperative Learning, Analisis Model Busana, pecah pola busana

\section{PENDAHULUAN}

Mata kuliah Analisis Model Busana, merupakan salah satu mata kuliah bidang studi wajib. Mata kuliah ini bertujuan untuk mengembangkan kreatifitas mahasiswa dalam analisis pola busana dan model busana serta pecah pola dasar busana untuk berbagai model. Dalam pelaksanaan perkulihan Analisis Model Busana, mahasiswa bekerja dan belajar secara perorangan (individual), mahasiswa mengerjakan tugas menganalisis pola sesuai bentuk tubuh, menganalisis model busana serta melakukan pecah pola dasar untuk membuat pola busana sesuai model. Dalam melakukan pecah pola dasar untuk membuat pola berbagai model busana, diperlukan ketelitian dan ketepatan. Untuk itu mahasiswa harus menguasai prinsip dasar membuat pola berbagai model kerah, pola berbagai model lengan, berbagai macam garis model busana, membuat pola berbagai macam model rok, pantalon, model draperi dsb.

Berdasarkan observasi dan studi dokumentasi yang penulis lakukan, hasil belajar Analisis Model Busana, mengenai kemampuan mahasiswa terutama dalam melakukan analisis pola dan pecah pola dasar, hasilnya belum optimal. Untuk itu perlu adanya peningkatan kemampuan dalam memahami dan menganalisis pola dan analisis model busana, sehingga mahasiswa dapat melakukan analisa pola dan pecah pola dasar dengan tepat. Sementara ini telah dilakukan upaya untuk memotivasi mahasiswa dalam belajar melakukan analisis pola maupun melakukan pecah pola dasar untuk membuat pola busana, yaitu dengan belajar kelompok. Belajar kelompok ini dilakukan untuk adanya kerjasama dan diskusi dengan teman, serta saling bertukar pengalaman, hasil pemikiran beberapa kepala akan lebih kaya daripada pemikiran satu kepala, hasil kerja sama lebih besar jumlahnya dari pada hasil pemikiran sendiri, sehingga hasil analisis pola maupun hasil pecah pola akan lebih baik. Saat ini motivasi belajar mahasiswa untuk belajar dan bekerja sama dalam suatu kelompok belum nampak adanya kolaborasi yang baik, karena pembelajaran belum dirancang dengan maksimal.

Salah satu model pembelajaran yang dapat mengakomodasi kepentingan untuk mengkolaborasikan pengembangan diri di dalam proses pembelajaran adalah model pembelajaran kooperatif (cooperative learning). Ide penting dalam pembelajaran kooperatif adalah membelajarkan kepada mahasiswa keterampilan kerjasama dan kolaborasi. Keterampilan ini sangat penting bagi

${ }^{1}$ Dra. As-as Setiawati.M.Si, adalah Dosen pada Program Studi Pendidikan Tata Busana FPTK UPI 
mahasiswa, karena pada dunia kerja sebagian besar dilakukan secara kelompok.

Pembelajaran kooperatif merupakan salah satu model pembelajaran yaitu mahasiswa belajar dalam kelompok kecil yang heterogen, dan dikelompokkan dengan tingkat kemampuan yang berbeda serta anggota kelompok yang tidak terlalu banyak. Jadi dalam setiap kelompok terdapat mahasiswa yang berkemampuan rendah, sedang, dan tinggi. Dalam menyelesaikan tugas, anggota saling bekerja sama dan membantu untuk memahami bahan pembelajaran dan tugas setiap anggota kelompok. Belajar belum selesai jika salah satu teman belum menguasai bahan pembelajaran dan dapat menyelesaikan tugasnya. Pemilihan model pembelajaran yang tepat dalam perkuliahan Analisis Model Busana akan mengaktifkan mahasiswa serta menyadarkan mahasiswa bahwa belajar secara berkelompok dan bekerjasama akan memberikan pengalaman-pengalaman belajar yang inovatif, menantang dan menyenangkan. Dosen hanya sebagai fasilitator untuk membentuk dan mengembangkan pengetahuan itu sendiri, bukan untuk memindahkan pengetahuan. Melalui pembelajaran kooperatif mahasiswa diharapkan dapat meningkatkan kemampuan berpikir dan memiliki motivasi yang tinggi dalam belajar Analisis Model Busana.

\section{METODOLOGI PENELITIAN}

Metode yang digunakan dalam penelitian ini adalah penelitian tindakan yang difokuskan pada situasi kelas yang lazim dikenal dengan "Classroom Action Research”. Menurut Supriyadi (2008) Classroom action research (CAR) pada hakikatnya merupakan rangkaian "riset-tindakan", yang dilakukan secara siklik, dalam rangka memecahkan masalah, sampai masalah itu terpecahkan. Subjek penelitian dipilih Dosen (team teching) dan mahasiswa pada perkuliahan Analisis Model Busana pada program studi Pendidikan Tata Busana Jurusan PKK FPTK UPI. Konsep pokok Classroom action research menurut Kurt Lewin terdiri dari empat komponen, yaitu : (1) perencanaan (planning), (2) tindakan (acting), (3) pengamatan (observing), dan (4) refleksi (reflecting). Hubungan keempat komponen itu dipandang sebagai satu siklus.

\section{HASIL DAN PEMBAHASAN}

Penelitian ini dilakukan dengan menerapkan pendekatan cooperative learning di dalam pembelajaran Analisis Model Busana, untuk meningkatkan motivasi dan hasil belajar mahasiswa dalam pecah pola busana. Hasil penelitian dapat ditafsirkan bahwa pendekatan cooperative leraning dapat dijadikan model pembelajaran untuk meningkatkan motivasi dan hasil belajar mahasiswa pada pembelajaran Analisis Model Busana, khususnya pada pecah pola busana. Tafsiran tersebut berdasarkan upaya dosen dalam menyusun program perkuliahan dengan cooperative learning dan implementasinya dalam pembelajaran sebagai hasil penelitian classroom action research. Aktivitas mahasiswa dapat dilihat pada pelaksanaan pembelajaran di kelas motivasinya dalam belajar dengan cooperative learning dan hasil belajar yang diperoleh.

Hasil belajar yang diperoleh mahasiswa, dapat dilihat bahwa kemampuan kognitif, afektif dan psikomotor, maka telah mencapai hasil belajar yang memuaskan. Sebagian besar (73,7\%) mahasiswa mendapat nilai A dan sebagian kecil (26,7\%) yang mendapat nilai B. Keadaan ini menunjukkan mahasiswa telah mencapai Mastery Learning khususnya dalam pecah pola busana. Hasil belajar mahasiswa dalam melakukan analisa dan faham gambar serta pecah pola busana dapat dilihat pada table berikut ini :

Tabel 1. Hasil Belajar Pecah Pola Busana

\begin{tabular}{|c|c|c|}
\hline Skor & $\begin{array}{c}\text { Jumlah } \\
\text { Mahasiswa }\end{array}$ & Prosentase \\
\hline 100 & 4 & 13.3 \\
\hline 90 & 11 & 36.7 \\
\hline 80 & 7 & 23.3 \\
\hline 70 & 8 & 26.7 \\
\hline 60 & 0 & 0 \\
\hline Jumlah & 30 & $100 \%$ \\
\hline
\end{tabular}

Nilai yang diperoleh dari nilai kelompok dan nilai individu, penilaian ini dari ketepatan dalam pecah pola yaitu menentukan perbandingan dari tiap bagian busana, ketepatan ukuran, ketepatan letak garis hias dan letak bagian-bagian detail model busana. Hasil belajar yang diperoleh mahasiswa seperti tergambar pada uraian di atas, merupakan dampak dari pengembangan model perkuliahan dengan pendekatan cooperative learning. Dalam kelompok kooperatif mahasiswa belajar bekerja sama, saling memberi dan menerima, saling menghargai pendapat dan belajar dari pengalaman teman serta saling menyamakan persepsi. Program perkuliahan yang dirancang oleh dosen pada perkuliahan Analisis Model Busana dengan pendekatan cooperative learning meliputi :

\section{Rencana Pengajaran}

Prinsip dasar tentang pembelajaran dalam penelitian ini adalah proses pembelajaran yang 
dapat meningkatkan motivasi dan hasil belajar mahasiswa baik kemampuan kognitif, afektif maupun psikomotor pada perkuliahan Analisis Model Busana khususnya pada pecah pola busana. Proses pembelajaran yang dilaksanakan bukan hanya sekedar transfer pengetahuan dan keterampilan serta gagasan dosen kepada mahasiswa, tetapi memberi kesempatan kepada mahasiswa untuk belajar dalam kelompok kecil yang heterogen melalui pendekatan cooperative learning. Dalam menyelesaikan tugas, anggota saling bekerja sama dan membantu untuk memahami bahan pembelajaran dan tugas setiap anggota kelompok. Belajar belum selesai jika salah satu teman belum menguasai bahan pembelajaran dan dapat menyelesaikan tugasnya. Pemilihan model pembelajaran yang tepat dalam perkuliahan Analisis Model Busana akan mengaktifkan mahasiswa serta menyadarkan mahasiswa bahwa belajar secara berkelompok dan bekerjasama akan memberikan pengalaman-pengalaman belajar yang inovatif, menantang dan menyenangkan.

Penggunaan pendekatan pembelajaran cooperative learning dalam penelitian ini dirancang sedemikian rupa dimulai dari menyusun satuan acara perkuliahan. Satuan acara perkuliahan merupakan satuan atau unit program yang berisi rencana penyajian satuan bahasan tertentu. Komponen-komponen pembelajaran pada satuan acara perkuliahan antara lain meliputi tujuan pengajaran yang hendak dicapai, materi dan kegiatan belajar mengajar, media dan alat pengajaran, serta evaluasi belajar menggunakan tes yang standar sebagai alat ukur kemajuan belajar siswa. (Syaiful Sagala, 2008 : 155).

Untuk pembelajaran dengan pendekatan cooperative learning, selain menyusun satuan acara perkuliahan, dosen menyusun lembar kerja untuk mahasiswa dan lembar observasi untuk dosen, karena dalam pembelajaran kooperatif mahasiswa belajar dalam kelompok kecil berdasarkan lembar tugas dari dosen. Sesuai dengan pendapat Anita Lie (2007) bahwa untuk menciptakan kelompok kerja yang efektif, dosen menyusun tugas sedemikian rupa sehingga setiap anggota kelompok menyelesaikan tugas sendiri agar yang lain bisa mencapai tujuan mereka.

Satuan Acara Perkuliahan dalam bentuk tertulis yang dirancang oleh dosen terdiri dari unsur-unsur sebagai berikut :

\section{a. Tujuan Pembelajaran}

Tujuan pembelajaran atau tujuan perkuliahan merupakan pedoman terhadap sesuatu yang akan dilakukan dan pedoman dalam menentukan unsur-unsur pembelajaran lainnya, sehingga apa yang dilakukan memiliki arah yang jelas dan tidak kabur. Sesuai dengn pendapat Ibrahim dan Nana Syaodih dalam Syaiful Sagala (2008 : 155) bahwa tujuan pembelajaran lebih diartikan sebagai perilaku hasil belajar yang diharapkan dimiliki para siswa setelah mereka menempuh proses permbelajaran.

\section{b. Materi Pembelajaran}

Materi pembelajaran atau materi perkuliahan merupakan yang disajikan dosen untuk diolah dan difahami oleh mahasiswa dalam upaya mencapai tujuab yang pembelajaran yang telah ditetapkan. Menentukan dan memilih materi perkuliahan harus berpedoman pada tujuan dan materi perkuliahan disusun secara sistematis dan berkesinambungan sesuai dengan struktur kurikulum dan silabus perkuliahan. Sesuai dengan pendapat Syaiful Sagala (2008 : 162) bahwa materi dan bahan pengajaran ditetapkan dengan mengacu pada mengacu pada tujuan-tujuan yang ingin dicapai.

c. Metoda Pembelajaran

Metoda pembelajaran adalah cara yang digunakan dosen dalam menyampaikan materi atau bahan perkuliahan untuk mencapai tujuan yang telah ditetapkan. Menurut Syaiful Sagala (2008 : 169) bahwa metode mengajar adalah cara yang digunakan oleh guru dalam mengorganisasikan kelas pada umumnya atau dalam menyajikan bahan pelajaran pada khususnya. Faktor-faktor yang harus diperhatikan dalam pemilihan metoda pembelajaran antara lain tujuan pembelajaran, materi atau bahan ajar, kondisi dan aktifitas belajar siswa /mahasiswa, fasilitas belajar mengajar dan waktu belajar yang tersedia. Metoda pembelajaran yang digunakan dosen pada perkuliahan Analisis Model Busana dengan pendekatan cooperative learning adalah ceramah, demonstrasi, tanya jawab dan pemberian tugas.

\section{d. Media dan Alat Pembelajaran}

Media dan alat pembelajaran segala sesuatu yang digunakan dalam rangka mencapai tujuan pembelajaran (Djamarah, Aswan Zain, 2006 : 47). Media dan alat pembelajaran harus berfungsi untuk mempertinggi proses pembelajaran. Penggunaan media dan alat pembelajaran harus berpedoman pada tujuan pembelajaran dan disesuaikan dengan bahan atau materi pembelajaran, kemudahan memperoleh media dan alat yang diperlukan serta kemampuan dosen 
dalam menggunakan media dan alat tersebut dalam proses pembelajaran.

Media dan alat pembelajaran akan membantu dosen dalam menyampaikan materi perkuliahan dan membantu mahasiswa memahami materi yang dipelajarinya. Sesuai pendapat Syaiful Sagala (2008 : 169) bahawa pendidikan yang disertai media yang tepat, selain memudahkan siswa dalam mengalami, memahami, mengerti dan melakukan juga menimbulkan motivasi yang lebih kuat ketimbang menggunakan kata-kata yang abstrak.

Media dan alat pembelajaran yang digunakan dalam perkuliahan Analisis Model Busana dengan pendekatan cooperative learning adalah alat-alat menggambar pola, media 2 dimensi berupa gambar dan media 3 dimensi berupa passpop (dummy), media proyeksi berupa OHP dan transparansi.

\section{e. Penilaian Hasil belajar}

Penilaian/evaluasi adalah suatu tindakan atau suatu proses untuk menentukan nilai dari sesuatu (Wand dan Brown dalam Djamarah 2008 : 50). Menentukan nilai dari sesuatu dalam kegiatan pembelajaran adalah menilai proses dan hasil dari pembelajaran tersebut. Penilaian proses untuk menilai pelaksanaan proses belajar mengajar yang telah diprogramkan dapat berjalan dan kenbdala apa yang ditemui untuk selanjutnya diperlukan untuk perbaikan rencana pembelajaran berikutnya. Evalusi hasil untuk menilai hasil belajar siswa/ mahasiswa pada penguasaan mmateri yang dipelajari.

Penilaian pada pembelajaran Analisis Model Busana dengan pendekatan cooperative learning, penilaian proses pembelajaran yaitu penguasaan materi teori dan praktek yang dilakukan melalui kelompok kooperatif mahasiswa. Penilaian kelompok kooperatif menggunakan lembar observasi untuk proses belajar kolaboratif, pola belajar tutor sebaya (peer group) dan belajar secara bekerjasama (cooperative). Untuk penilaian tugas berdasarkan lembar penilaian, yaitu tugas yang dibuat secara kelompok dan penilaian tugas secara individu.

\section{Proses Belajar Mengajar}

Melaksanakan segala sesuatu yang telah diprogramkan merupakan kegiatan belajar mengajar dalam suatu proses pendidikan. Dalam kegiatan belajar mengajar ini akan menentukan tercapainya tujuan yang telah ditetapkan. Dalam suatu kegiatan belajar mengajar akan terlibat guru/dosen dan siswa/mahasiswa, guru mendorong siswa untuk aktif

Proses belajar mengajar Analisis Model Busana dengan pendekatan cooperative learning, dilaksanakan sesuai dengan langkah-langkah kegiatan belajar mengajar yang telah direncanakan. Pada tahap persiapan dosen mempersiapkan segala sesuatu yang terkait dengan pelaksanaan perkuliahan. Pada tahap ini dosen melakukan kegiatan; menyusun satuan acara perkuliahan (SAP), menyusun lembar tugas kerja mahasiswa untuk pengajaran kooperatif, membuat lembar observasi, meyiapkan ruang belajar, media, bahan pembelajaran untuk teori dan untuk belajar kelompok bagi mahasiswa.

Pada tahap penyajian dosen menyajikan informasi tentang materi pembelajaran dan cara melakukan suatu pekerjaan sesuai dengan materi pembelajaran dengan menggunakan strategi yang telah direncanakan. Pada tahap ini dijelaskan pula cara belajar dalam kelompok kooperatif sesuai dengan lembar tugas yang telah dibuat oleh dosen.

Pada tahap aplikasi mahasiswa melakukan kegiatan belajar dalam kelompok kooperatif, sesuai dengan lembar tugas yang diberikan dosen. Kegiatan dosen melakukan observasi dan pengawasan pada kegiatan belajar mahasiswa, bila diperlukan dosen memberikan pengarahan.

Tahap selanjutnya adalah tahap penilaian untuk menilai sejauh manakah pengetahuan yang diperoleh dan transformasi dapat dimanfaatkan sebagai hasil belajar. Pada tahap penilaian dosen menilai hasil kerja mahasiswa secara kelompok dan secara individu. Dalam pembelajaran kelompok kooperatif, nilai yang diperoleh mahasiswa adalah nilai kelompok dan nilai individu, karena setiap individu akan menyumbangkan nilai untuk kelompoknya. Oleh karena itu belajar dalam kelompok kooperatif setiap orang akan belajar dari peergroupnya dan harus proaktif sebagai anggota kelompok, karena setiap orang diberi kesempatan untuk mengemukakan pendapatnya tentang tugas yang harus dibuat.

\section{Evaluasi Proses dan Hasil Belajar}

Evaluasi atau penilaian merupakan komponen pembelajaran untuk mengukur pencapaian tujuan pembelajaran. Pengajaran yang efektif dapat dilihat dari hasil evaluasi, dari hasil evaluasi dapat diperoleh feedback yang dipakai untuk memperbaiki dan merevisi bahan atau metode pengajaran atau untuk menyesuaikan 
bahan dengan perkembangan ilmu pengetahuan (Syaiful Sagala 2008 : 171).

Pelaksanaan evaluasi hasil belajar Analisis

Model Busana khususnya pecah pola busana dengan pendekatan cooperative learning, diarahkan untuk mengukur dan menilai performansi mahasiswa dalam kemampuan kognitif, afektif dan psikomotor. Kemampuan mahasiswa tersebut dapat dilihat dari kegiatan belajar mahasiswa dalam kelompok kooperatif dan melalui hasil tugas yang dikerjakan dalam kelompok kooperatif. Hasil belajar yang baik menunjukan dengan belajar berkelompok akan memberikan pengalaman bahwa mahasiswa tidak hanya belajar dan menerima apa yang disajikan oleh dosen dalam pelaksanaan perkuliahan, melainkan mahasiswa bisa juga belajar dari mahasiswa lainnya, dan sekaligus mempunyai kesempatan untuk membelajarkan mahasiswa yang lain. Kondisi seperti ini akan menimbulkan motivasi belajar bagi mahasiswa karena proses pembelajaran dengan cooperative learning ini mampu merangsang dan menggugah potensi mahasiswa secara optimal, dalam suasana belajar pada kelompok-kelompok kecil (Stahl dalam Wydianingsih 2008).

Evaluasi hasil belajar dapat dijadikan masukan untuk perbaikan rencana pembelajaran dalam bentuk Satuan Acara Perkuliahan (SAP) yang dibuat oleh dosen. Selanjutnya dilakukan perbaikan pada pelaksanaan perkuliahan dan penggunaan alat penilaian yang dilakukan oleh dosen, sehingga diperoleh model pembelajaran cooperative learning yang dapat diterapkan pada pembelajaran tata busana.

\section{Dampak Penggunaan Model Pembelajaran Coopertive Learning}

Pembelajaran Analisis Model Busana khususnya pecah pola busana dengan pendekatan model pembelajaran cooperative learning, dari hasil penelitian ternyata memberikan dampak pada peningkatan motivasi dan hasil belajar mahasiswa. Penggunaan pendekatan pembelajaran cooperative learning merupakan upaya untuk kepentingan belajar mahasiswa, agar mahasiswa senang dan bergairah belajar pecah pola busana yang selama ini dirasakan sulit oleh mahasiswa. Motivasi merupakan faktor yang sangat penting dalam belajar, oleh karena itu guru/dosen harus menciptakan suasana belajar yang kondusif yang dapat membangkitkan semangat dan motivasi belajar bagi mahasiswa.

Inti dari cooperative learning adalah belajar berkolaborasi dalam kelompok kooperatif. Pada saat mahasiswa belajar dalam kelompok akan berkembang suasana belajar yang terbuka dalam dimensi kesejawatan, karena pada saat itu akan terjadi proses belajar kolaboratif dalam hubungan pribadi yang saling membutuhkan. Pada saat itu juga mahasiswa yang belajar dalam kelompok kecil akan tumbuh dan berkembang pola belajar tutor sebaya (peer group) dan belajar secara bekerjasama (cooperative). Merasakan duka dan suka bersama, gagal dan berhasil dirasakan bersama. Memiliki tanggung jawab terhadap tiap mahasiswa lain dalam kelompoknya, disamping tanggung jawab terhadap diri sendiri, dalam mempelajari materi yang dihadapi. Keadaan inilah yang meningkatkan motivasi belajar mahasiswa dalam belajar Analisis Model Busana khususnya pecah pola busana.

Hasil belajar dilihat dari performansi mahasiswa dalam kemampuan kognitif, afektif dan psikomotor dalam mempelajari pecah pola busana melalui perkuliahan Analisis Model Busana mengalami peningkatan. Sebagian besar (73,3 \%) mahasiswa memperoleh nilai A dan sebagian kecil (26,7 \%) memperoleh nilai B. Keadaan ini menunjukkan terjadi peningkatan hasil belajar Analisis Model Busana khususnya pecah pola busana pada mahasiswa dengan pendekatan cooperative learning.

Setelah uji coba pendekatan pembelajaran dengan cooperative learning pada perkuliahan Analisis Model Busana berakhir, mahasiswa diminta untuk mengisi lembar pertanyaan tentang keterlibatannya dalam kerja kelompok, sehingga dalam proses belajar dengan pembelajaran kooperatif setiap anggota kelompok terlibat aktif. Pendapat mahasiswa mahasiswa dalam keterlibatannya dalam kelompok kooperatif pada perkuliahan Analisis Model Busana, ditunjukan dengan sikap yang positif dan bervariasi. Pendapat tersebut dapat dilihat pada tabel di halaman berikut 
Tabel 2

Pendapat Mahasiswa Tentang keterlibatannya Pada Kelompok Kooperatif

Dalam Mengerjakan Tugas Pecah Pola

\begin{tabular}{|c|c|c|c|c|c|}
\hline \multirow[b]{2}{*}{ No } & \multirow[b]{2}{*}{ Pernyataan } & \multicolumn{4}{|c|}{ Pendapat Mahasiswa } \\
\hline & & $\begin{array}{l}\text { SS } \\
(\%)\end{array}$ & $\begin{array}{l}\mathrm{S} \\
(\%)\end{array}$ & $\begin{array}{c}\text { TS } \\
(\%)\end{array}$ & $\begin{array}{l}\text { STS } \\
(\%)\end{array}$ \\
\hline 1. & $\begin{array}{l}\text { Setiap anggota kelompok berpartisipasi aktif dalam pembuatan tugas dengan } \\
\text { kelompok kooperatif }\end{array}$ & 36,7 & 53.3 & 10 & \\
\hline 2. & Setiap anggota kelompok saling membantu untuk mengemukakan pendapat & 33,3 & 60 & 6.7 & \\
\hline 3. & $\begin{array}{llll}\begin{array}{l}\text { Setiap anggota kelompok saling } \\
\text { mengerjakan tugas }\end{array} & \text { mendengarkan pendapat temannya dalam } \\
\end{array}$ & 43,3 & 43,3 & 13.4 & \\
\hline 4. & Setiap anggota kelompok saling memperhatikan satu sama lain & 40 & 43,3 & 16,7 & \\
\hline 5. & Setiap anggota kelompok saling bertanya untuk mengerjakan tugas & 53.3 & 40 & 6,7 & \\
\hline 6. & Dalam kelompok kerja tidak ada yang mendominasi pembicaraan & 46,7 & 30 & 23,3 & \\
\hline 7. & $\begin{array}{l}\text { Pembelajaran dengan kelompok kooperatif membuat saya termotivasi untuk } \\
\text { melakukan tugas dengan baik }\end{array}$ & 56,7 & 33,3 & 10 & \\
\hline 8. & $\begin{array}{l}\text { Pembelajaran dengan kelompok kooperatif membuat saya mudah memahami cara } \\
\text { melakukan pecah pola }\end{array}$ & 53,3 & 33,3 & 13,4 & \\
\hline 9. & $\begin{array}{l}\text { Pembelajaran dengan kelompok kooperatif membuat saya termotivasi untuk } \\
\text { mengeluarkan pendapat }\end{array}$ & 30 & 36,7 & 33,3 & \\
\hline 10 & Pembelajaran dengan kelompok kooperatif membuat saya berfikir keras dan kreatif & 56,7 & 33,3 & 10 & \\
\hline 11. & $\begin{array}{l}\text { Pembelajaran dengan kelompok kooperatif membuat saya termotivasi bertukar } \\
\text { pendapat dengan teman }\end{array}$ & 30 & 46,7 & 23,3 & \\
\hline 12. & $\begin{array}{l}\text { Pembelajaran dengan kelompok kooperatif membuat saya berani mengemukakan } \\
\text { pendapat }\end{array}$ & 46,7 & 53,3 & 0 & \\
\hline 13. & $\begin{array}{l}\text { Pembelajaran dengan kelompok kooperatif membuat saya termotivasi untuk } \\
\text { melakukan tugas dengan baik }\end{array}$ & 56,7 & 33,3 & 10 & \\
\hline 14. & $\begin{array}{l}\text { Pembelajaran dengan kelompok kooperatif memper-kaya wawasan saya dalam pecah } \\
\text { pola busana }\end{array}$ & 63,3 & 36,7 & 0 & \\
\hline 15. & $\begin{array}{l}\text { Pembelajaran dengan kelompok kooperatif membuat saya mengetahui kelemahan } \\
\text { saya dalam pecah pola }\end{array}$ & 66,7 & 33,3 & 0 & \\
\hline 16. & $\begin{array}{l}\text { Pembelajaran dengan kelompok kooperatif membuat saya merasa pecah pola } \\
\text { merupakan materi yang sangat menyenangkan }\end{array}$ & 66,7 & 30 & 3,3 & \\
\hline 17. & Dosen membimbing kami selama mengerjakan tugas pecah pola & 50 & 50 & 0 & \\
\hline 18. & $\begin{array}{l}\text { Dosen memberikan keleluasaan kepada kami untuk saling mengemukakan pendapat } \\
\text { dalam kelompok kooperatif }\end{array}$ & 53,3 & 46,7 & 0 & \\
\hline 19. & $\begin{array}{l}\text { Dosen memotivasi kami untuk bekerja secara kolabo-ratif agar diperoleh hasil } \\
\text { belajar yang lebih baik }\end{array}$ & 53,3 & 46,7 & 0 & \\
\hline 20. & $\begin{array}{l}\text { Dosen mengamati setiap kegiatan pada kelompok kooperatif sehingga kami } \\
\text { termotivasi untuk bekerja lebih baik }\end{array}$ & 56,7 & 43,3 & 0 & \\
\hline
\end{tabular}

\section{KESIMPULAN}

Dari uraian hasil penelitian dan pembahasan di atas, maka akan dikemukakan kesimpulan sebagai berikut:

1. Model pembelajaran cooperative learning pada perkuliahan Analisis Model Busana memberikan kesempatan kepada mahasiswa untuk belajar dalam kelompok kooperatif, dalam suasana belajar yang terbuka dalam dimensi kesejawatan, terjadi proses belajar kolaboratif dalam hubungan pribadi yang saling membutuhkan, suasana belajar yang menumbuhkan motivasi belajar bagi mahasiswa

2. Model pembelajaran cooperative learning dalam meningkatkan motivasi dan hasil belajar mahasiswa di implementasikan pada pembelajaran Analisis Model Busana, didukung oleh kemampuan dosen dalam merencanakan program perkuliahan, kemampuan dosen dalam membuka perkuliahan, sikap dosen dalam proses perkuliahan, penguasaan dosen pada materi perkuliahan, kemampuan dosen menggunakan media pembelajaran, melakukan evaluasi dan kemampuan menutup perkuliahan.

3. Pemilihan media perkuliahan yang sesuai dengan tujuan dan materi analisis model busana dengan pendekatan cooperative learning, dapat menunjang dalam meningkatkan motivasi belajar mahasiswa, karena mahasiswa mudah memahami materi yang dipelajari. 
4. Peningkatan hasil belajar mahasiswa pada perkuliahan Analisis Model Busana khususnya pada pecah pola busana dengan pendekatan cooperative learning, dilihat dari kemampuan kognitif, afektif dan psikomotor sebagian besar mencapai nilai $\mathrm{A}$, yang ditunjukan dari hasil pecah pola yang tepat sesuai model.

5. Sebagian kecil mencapai nilai $B$, nilai ini masuk kategori baik, pencapaian nilai ini dalam pembuatan masih ada sedikit kekurangan dalam hasil pecah pola yang dibuat.

\section{SARAN}

Dari kesimpulan penelitian di atas, maka sebagai bahan pertimbangan untuk pengembangan pembelajaran pada Program Studi Pendidikan Tata Busana Jurusan PKK FPTK UPI, perlu diajukan saran sebagai berikut :

1. Dosen Prodi Pendidikan Tata Busana

Pendekatan pembelajaran cooperative learning dapat digunakan pada perkuliahan tata busana, karena dengan belajar dalam kelompok kooperatif mahasiswa belajar dalam suasana belajar yang terbuka dalam dimensi kesejawatan, terjadi proses belajar kolaboratif dalam hubungan pribadi yang saling membutuhkan, suasana belajar ini yang menumbuhkan motivasi belajar bagi mahasiswa, disini mahasiswa saling memberi dan menerima dari pengalaman temantemannya. Untuk itu model pembelajaran ini dapat diterapkan pada mata kuliah lain pada Prodi Pendidikan Tata Busana
2. Bagi Penelti Selanjutnya

Peneliti lain yang tertarik pada pengembangan Model pembelajaran cooperative learning, dapat melakukan penelitian pengembangan pendekatan tersebut pada mata kuliah lain pada Prodi Tata Busana, atau pada jenjang pendidikan yang berbeda.

\section{DAFTAR PUSTAKA}

Anita Lie, 2007, Cooperative Learning, Mempraktekan Cooperative Learning di Ruang-ruang Kelas,Jakarta. Grasindo

Djamarah, Zain, 2006, Strategi Belajar Mengajar, jakarta, Rineka Cipta

Ibrahim R dan Sukmadinata N S, 1996, Perencanaan Pengajaran, Jakarta Rineka Cipta

Sagala Syaiful, 2007, Konsep dan Makna Pembelajaran, Bandung: Alfabeta.

Slavin, R E. 1994, Cooperative Learning; Theori, Research and Practice. Boston: Allyn and Bacon.

Supriyadi, 2008, Penelitian Tindakan Kelas (Classroom Action Research), Detik Com

Sudjana, N. 1995. Dasar-dasar Proses Belajar Mengajar. Bandung: Sinar Baru Algesindo Offset

Widyaningsih dkk, 2008, Cooperative Learning Sebagai Model Pembelajaran Alternatif Untuk Meningkatkan Motivasi Belajar Matetamtika. 